ROCZNIKI PSYCHOLOGICZNE/ANNALS OF PSYCHOLOGY

2019, XXII, 2, 151-175

DOI: http://dx.doi.org/10.18290/rpsych.2019.22.2-4

MARIA CHEŁKOWSKA-ZACHAREWICZ

MATEUSZ PALIGA

University of Silesia in Katowice, Institute of Psychology, Poland

\title{
MUSIC EMOTIONS AND ASSOCIATIONS \\ IN FILM MUSIC LISTENING: \\ THE EXAMPLE OF LEITMOTIFS \\ FROM THE LORD OF THE RINGS MOVIES
}

\begin{abstract}
The aim of the present study was to investigate which musical emotions and associations appeared while listening to leitmotifs in film music. A sample of 157 participants took part in the study, in which musical associations and emotions were analysed in relation to seven groups of musical themes from The Lord of the Rings films (LOTR). The LOTR soundtrack is a good example of the use of symbols in music to represent ideas, characters, etc. The results show that both the respondents' associations and the musical emotions they experienced were related to the characteristics of musical motifs. The results are discussed in relation to the assumed features of musical motifs composed by Howard Shore.
\end{abstract}

Keywords: film music; leitmotif; music-induced emotions; affect; The Lord of the Rings.

\section{INTRODUCTION}

Music is a kind of language that represents different feelings and emotions (Davies, 2010). It relates our experience of and familiarity with music to its structure and elements, which leads to finding meaning (Meyer, 1974). The

Corresponding author: MARIA CHEŁKOWSKA-ZACHAREwICZ-University of Silesia, Institute of Psychology, ul. Grażyńskiego 53, 40-126 Katowice, Poland; e-mail: maria.chelkowska-zachare wicz@us.edu.pl

Funding: This research was conducted with no funding.

We wish to thank Nikolas Wojtas for his support in the process of preparing the musical excerpts for the study. 
symbols encompassed in music are strongly related to certain emotions (Juslin \& Sloboda, 2013). The emotional aspect of music seems indisputable. Music has been used to induce moods (Västfjäll, 2001), express emotions (Juslin, 2013a), and regulate emotional state (Saarikallio, 2011).

Research on music emotions has a strong and broad tradition (Juslin \& Sloboda, 2010), which has led to numerous studies in the last 20 years. Simultaneously with music emotion research, attention was devoted to film music, a fine example of emotionally strong music genre. Although the analysis of the emotional aspect of film music was somehow neglected, it has been implied that this genre is supposed to evoke strong emotions. The available literature attests to an interest in how music influences the perception of movies or the absorption of the viewer, etc. (for more, see: Cohen, 2010, 2014) rather than in what kind of emotions are felt when listening to film music.

The assumption that music has a strong effect on film perception is the basic reason for the presence of music motifs in movies (Green, 2010). However, to our knowledge, it has scarcely been tested in music emotion research if certain emotions indeed appear in listeners of film music themes.

\section{Emotional reactions to music}

When listening to music we may consider music emotions as either perceived or felt (Gabrielsson, 2001). While we can perceive the emotional expression of a music piece, the emotional reactions that are evoked by music and therefore subjectively experienced may appear different from the perceived ones in type or strength (Kallinen \& Ravaja, 2006). As music emotions tend to differ from real-life emotions (Juslin, Liljeström, Västfjäll, Barradas, \& Silva, 2008), dedicated tools have been developed for their measurement. Such tools include the Geneva Emotional Music Scale (Zentner, Grandjean \& Scherer, 2008) or the Geneva Emotional Music Affective Scale (Coutinho \& Scherer, 2017).

The emotional reactions that are experienced in music listening may be a result of various mechanisms that are described in the music emotion literature. Juslin (2013b) established the BRECVEMA model that comprehensively covers emotional variability and its correlates in music emotions. BRECVEMA stands for eight mechanisms: brain stem reflex, rhythmic entrainment, evaluative conditioning, emotional contagion, visual imagery, episodic memory, musical expectancy, and aesthetic judgement (Juslin \& Västfjäll, 2008; Juslin, 2013b). These mechanisms are types of mediators between music and emotional reactions and lead to the elicitation of music emotions in different ways (Juslin, Harmat, \& 
Eerola, 2014). Brain stem reflex, rhythmic entrainment, and emotional contagion relate to reactions that occur with low cultural influence (Juslin, 2013b). By contrast, visual imagery, episodic memory, and evaluative conditioning involve elements that are not directly related to music, such as associations, past events, or expectations that are results of subjects' knowledge and experience and are therefore strongly influenced by culture (Juslin, 2013b). Musical expectancy and aesthetic judgement are also related to subjects' knowledge and cultural background.

An indication that associations may be a possible mediator in the induction of emotional reactions by music (Konečni, 2008) and that they may be responsible for interpersonal differences in the emotional experience of music appears not only in the BRECVEMA model. Personal stories including a situational context, memories, and knowledge may be triggered by music and lead to different emotional reactions that change according to these factors (Gabrielsson, 2010).

\section{The role of emotions in film music}

Film music adds an emotional dimension to the two-dimensional image (Cohen, 2010; Hagen, 1971), thus playing important functions in movies (Cohen, 1998). A growing body of research on film music in the past two decades shows academics' great interest (see: Neumeyer, 2013) in investigating the impact that film music has on viewers' mood, perception, interpretation, and memory of film information (e.g., Boltz, 2004; Cohen, 1998, 2010).

Film music can evoke and enhance spectators' emotions, as well as create a more convincing atmosphere of the presented time and place (Prendergast, 1992). When played parallelly with a scene from a movie, music can highlight its emotional aspects (Boltz, 2001). For example, the emotion of joy experienced while watching a scene of old friends reuniting after years of separation can be accentuated by music that conveys a sense of happiness and rejoicing. The soundtracks from Alfred Hitchcock's Psycho or Steven Spielberg's Jaws are among the most vivid examples of film music evoking emotions of fear in the viewers. Music may also change the electrodermal responses (Thayer \& Levenson, 1983), which can serve as an objective indicator of its emotional impact on spectators. Certain emotions can also be evoked or expressed by music with the use of music cues. For example, by means of falling pitch contour, fast tempo/speaking rate, and rising pitch contour in the music themes of Nazgûl in The Fellowship of the Ring Howard Shore conveyed threat, danger, and fear (Reymore, 2018). 
Due to the relations, learned in ontogenetic development, between elements of music and emotions, music can shape the perception and interpretation of a movie scene and characters' actions (Bordwell \& Thompson, 2008; Tan, Spackman, \& Wakefield, 2017; Marshall \& Cohen, 1988; Bolivar, Cohen, \& Fentress, 1994; Cohen, 1993). Melodies in minor key with syncopated rhythm and sudden rhythm changes bring to mind an emotional reaction of anger, whereas constant pitch and slow melodies may be perceived as sad and melodies in a major key with simple consonant harmony are associated with the expression of joy (Juslin \& Sloboda, 2013).

Different emotional cues in music can influence the comprehension of events occurring in the film; this may take place a result of music accompanying a particular scene (Boltz, 2001) or as a result of music foreshadowing or presented before a scene (Tan, Spackman, \& Bezdek, 2007). Film music can also affect the interpretation of characters' behaviors (Bolivar et al., 1994) as well as the memory of events or characters depicted in the film (Cohen, 1998). Music emotionally congruent with the film can accentuate its emotional aspects, while incongruent music may attenuate whatever emotional situations are displayed (Boltz, 2001; Boltz, Schulkind, \& Kantra, 1991). Music can serve as a cue that encourages spectators to develop expectations about what is going to happen in the film and to anticipate it to happen (Boltz, 2001). This conclusion corresponds with Meyer's (1974) point that music expectations lead to affective states, as well as with Huron's (2003) theory of musical expectation and the musical expectancy mechanism in the BRECVEMA model (Juslin, 2013b).

In film music, designed to engage the audience, composers often use associations such as situational and context factors to elicit emotions. As an example of evaluative conditioning mechanism, Juslin (2013b) mentioned a situation when the experienced emotion is a result of an earlier exposure to a given musical fragment, which co-occurred many times with a specific situation or person. In this way, the affective meaning is transferred from the latter stimulus to the music fragment. This mechanism, under the name of leitmotif, was utilized by Wagner in his music dramas (Juslin, 2013b), where certain themes occur together with specific characters, places, or situational contexts.

\section{Leitmotif}

To thoroughly understand the meaning of leitmotif, it is important to embed the presented idea in a wider, semiotic context. As a science, semiotics studies the relation that exists between the signifier (something physical, such as 
a gesture or sound) and the signified (an image or concept the signifier refers to). Among six types of signs, namely: symptoms, signals, icons, indexes, names, and symbols, the last one is of particular interest in explaining the concept of musical leitmotif. A symbol is a sign that stands for its referent in an arbitrary, conventional way. Many signifiers can be symbolic - words, objects, figures, or sounds, to name a few (Sebeok, 2001). Music, including film music, can also serve as a symbol, and the musical leitmotif seems to be a paramount example. The primary role of a leitmotif is, in essence, to stand for the character, object, or place it represents (i.e., a sign function). A leitmotif is therefore established by the composer through signifier-signified proximity (Chattah, 2006).

Leitmotif (Ger. "leading motif") is a recurring short musical theme (Green, 2010) or idea (Hanning, 2002; Whittall, 2001). As a music-based signifier, it can be identified as a simple melody, usually only a few measures in length (Green, 2010; Nagari, 2015). It refers to a signified, which can be a person, an object, a place, idea, a state of mind, a supernatural force, or any other ingredient in a dramatic work, including an emotion, plot development, or recurring dramatic themes (DePree, 2017; Provenzano, 2008). Musical leitmotifs that signify symbolic reality, such as certain characters, places, ideas, etc., subsequently appear every time that the symbolic reality is shown or is about to be shown on the screen (Walus, 2012). To establish the connection of a leitmotif with its referent, the former needs to be repeated a few times for the audience to understand the association (Green, 2010). Once the basic identifications are made, leitmotifs can undergo various changes, including rhythmic, intervallic, or harmonic changes, due to the development of storyline or characters in the film (Hanning, 2002; Walus, 2012). However, the changes cannot be major ones, so that leitmotifs retain their identity (Vilaro \& Orero, 2013), remain recognizable for the audience (Green, 2010), and play particular roles in the films they are part of. Musical leitmotifs provide the signified objects with a new narrative dimension (Otero, 2015), by using music in the objects' stories (Nagari, 2015). Serving as a signifier of changes happening to the character, the motif reappears throughout the film, generating meaning and evoking emotions. Being a musical representation of a character or idea, a leitmotif can symbolize that character even if he or she appears in disguise (Green, 2010). Finally, a leitmotif can work as a metonymy, having the power to fully replace the element it signifies (Vilaro \& Orero, 2013) if the signified is absent in the visuals or dialogue (Chattah, 2006). The overall significance of leitmotifs was noted by Richards (2016, p. 1), who pointed out that musical themes "can become part of an entire film's 
identity, to the point where they are often referred to as 'the theme from' the film in question."

\title{
Leitmotifs in The Lord of the Rings movies
}

One of the most prominent examples of musical leitmotifs used in cinematography is Howard Shore's score for Peter Jackson's The Lord of the Rings (LOTR) trilogy. Shore won two Academy Awards (in 2002 and 2004) for the best film score for the music composed for Jackson's movies (Young, 2007), as well as a Grammy Award; he was also nominated for a BAFTA Film Award and a Golden Globe. The music he composed for the film adaptation of John Ronald Reuel Tolkien's novel has expanded from the initially released soundtrack to include a limited edition of Complete Recordings, rare archived recordings, symphonic concerts, and live cinematic performances (White, 2016), becoming one of the significant factors in the film's success (Marchwica, 2018).

In the LOTR movies, Howard Shore created an almost 9-hour-long symphonic poem (Marchwica, 2018) with over ninety specific musical themes (Adams, 2010). Using characteristic instruments and sound effects, he was able to coin an intricate collection of leitmotifs that enabled him to use music to illustrate the reality of Jackson's film adaptation of Tolkien's fictional world called the Middle-earth, in which the action of The Lord of the Rings takes place. The abundance of leitmotifs encompasses the main characters (Marchwica, 2018) and the entire races of Men, Elves, Orcs, and Hobbits (Tolkien, 2002), as well as lands, key props (Young, 2007) such as the One Ring (a fictional artifact that once belonged to the title character and the main antagonist), and the general ideas of good and evil. Shore constructed the themes in such a way that subtle connections may be seen between the motifs (Adams, 2010), which makes the music even more illustrative of Tolkien's world. For all the aforementioned reasons and due to the use of similar thematic material throughout all three instalments of The Lord of the Rings movies, Howard Shore's work provides excellent material for musematic analysis (Young, 2007).

\begin{abstract}
Aim of the study
The purpose of this study was to analyze the emotions and associations that appear while listening to film music, with motifs from the LOTR soundtrack as the music material. Although there is some literature on leitmotifs and their function in film and dramatic music, film music studies relate more broadly to the functions of film music as such (Cohen, 2010, 2014). To our knowledge,
\end{abstract}


there has been little focus in research on how emotions and associations are related to leitmotifs. Therefore, this study is an exploratory one.

Leitmotifs in the LOTR soundtrack can be organized into groups that relate to certain characters or contexts. For example, there is a group of musical motifs connected with the artefact called the ring of power, or with the fictional race of hobbits (Tolkien, 2002). Each motif may be recognized as a symbol of some ideas, features, and emotions. The first aim of this study was to find out what kind of music-induced emotions emerge when listening to motifs from each group. To address this problem, the first question was formulated: Q1: What music emotions are felt when listening to groups of motifs from the LOTR soundtrack?

The musical motif groups mentioned above are different in their character and in the message that they are supposed to deliver. These differences can be observed in music structure (Adams, 2010; Marchwica, 2018) and in the interpretation of music itself (see Table 1). However, there remains the question of whether these differences can translate into feelings that appear while listening to music. The second question concerned this matter and read as follows: Q2: Do the music-induced emotions that appear while listening to musical motif groups differ across these groups?

To deepen this exploratory study, our aim was also to analyze what kind of thoughts, ideas, and associations appear when listening to the music themes from the motif groups. In order to supplement the analysis of emotional reactions to film music and to investigate if Shore's leitmotifs are interpreted in accordance with his intention, we formulated the third question: Q3: What associations occur when listening to the motif groups from the LOTR soundtrack?

\section{METHOD}

\section{Sample and procedure}

The study was conducted via Concerto v4, a platform for online testing. The participants were recruited via convenience sampling from February to August 2017. The link to the study website was distributed among the LOTR forum users, on Facebook, and on the website of a Polish film music radio RMF Classic. The survey started with a consent form, followed by the explanation of the study timeline. Each subject: (1) listened to one randomly chosen musical motif from the LOTR for 24 to 59 seconds (the listening time depended on the 
musical theme); (2) assessed the emotions felt while the music was being played in a loop for the second time; (3) responded to the question about associations while the music was being played in a loop for the third time; and (4) filled the sociodemographic data and familiarity with the LOTR music. Stages 2 and 3 were repeated twice, which means each participant listened to two random music pieces. However, some of the participants chose to listen to only one music excerpt.

The participants in the study were 95 women, 31 men, and 31 subjects who did not indicate their sex; they ranged in age from 16 to $56(M=26.83, S D=$ $=6.61)$. Familiarity with the LOTR films was average in the sample $(M e=5.00$ on a scale of 1 to 10) and familiarity with the LOTR soundtrack was low $(M e=$ $=2.00$ on a scale of 1 to 10 ). The participants provided 219 to 230 answers on felt emotions and 203 sets of answers on associations.

\section{Measures and material}

Measurement of music-induced emotions. The broad array of possible emotional reactions to music should not be reduced to a short list of basic emotions (Chełkowska-Zacharewicz \& Janowski, in review). It is therefore advisable to use dedicated measures in music emotion studies. One of the most popular and comprehensive music emotion scales is the Geneva Emotional Music Scale (GEMS; Zentner et al., 2008) which has been used in a number of music emotion studies since its inception (Coutinho \& Scherer, 2017). It encompasses diverse emotional reactions that appear while listening to music. Therefore, to measure emotional reactions to film music we chose the Polish adaptation of GEMS (GEMS-PL; Chełkowska-Zacharewicz \& Janowski, 2016; Chełkowska-Zacharewicz \& Janowski, in review). GEMS (Zentner et al., 2008) consists of nine scales that represent emotional reactions to music, which can be reduced to three dimensions (vitality, unease, and sublimity). The Polish version did not replicate the second-order factor structure of GEMS and has one additional scale, Being Moved (Pol. Wzruszenie), ${ }^{1}$ which was included in the final version of the adaptation procedure. Thus, GEMS-PL consists of 10 scales (three items each): Peacefulness, Tenderness, Joyful Activation, Tension, Power, Wonder, Transcendence, Sadness, Nostalgia, and Being Moved with Cronbach's alpha ranging

${ }^{1}$ The Being Moved (Pol. Wrruszenie) scale consists of items related to tearfulness in GEMS, and might be interpreted in GEMS-PL as a feeling similar to but not the same as being moved/touched. 
from .75 to .92 . The respondent evaluates the intensity of feelings when listening to a music excerpt on a scale from 1 (not at all) to 5 (very strongly).

Measurement of associations. We measured the associations occurring while listening to the LOTR music motifs by asking the participants an openended question: "What comes to your mind when you are listening to this music fragment? What associations do you have with it?". No specific number of associations was required.

Musical excerpts. The musical excerpts contained audio material only and were cut out of the original the LOTR soundtrack in Audacity 2.1.2 software. The length of each piece varied from 24 to 59 seconds (see Table 1) depending on the motif length. To assure that the most important symbols of the LOTR story were represented, we chose seven groups according to the analysis presented by Adams (2010) with a total of 15 the LOTR musical motifs as their representations (see Table 1). Table 1 includes the information about musical symbols and the symbolized reality represented in each group, which was used in further analysis to compare the target emotions and associations with the actual music-induced emotions and associations that occurred when listening to LOTR music motifs.

Table 1. Musical Motif Groups With Encompassing Musical Motifs, Their Music Symbols, and Symbolized Reality

\begin{tabular}{|c|c|c|c|c|}
\hline No. & Motif group & $\begin{array}{l}\text { Musical motifs } \\
\text { (Adams, 2010) } \\
\end{array}$ & Music symbols (sign) & Symbolized reality (referent) \\
\hline 1 & $\begin{array}{l}\text { Good/Nature } \\
(38)\end{array}$ & $\begin{array}{l}\text { Nature's Reclamation } \\
\left(28^{\prime}, 17\right), \text { The White } \\
\text { Rider }(27,, 21)\end{array}$ & $\begin{array}{l}\text { - soprano theme; rising } \\
\text { melody } \\
\text { - clear orchestral colors } \\
\text { (Adams, 2010); links with } \\
\text { Nature's Reclamation theme }\end{array}$ & $\begin{array}{l}\text { —power, purity } \\
\text { - hope of the good }\end{array}$ \\
\hline 2 & Evil (43) & $\begin{array}{l}\text { Orc Theme }(24 ", 18), \\
\text { The Five Beat Pattern } \\
(37 ", 8) \text {, Ring Wrights } \\
(59 ", 17)\end{array}$ & $\begin{array}{l}\text { - harsh; low brass melody } \\
\text { (Young, 2007) } \\
\text { —strong metric and rhyth- } \\
\text { mic patterns; low register; } \\
\text { lower brass instruments } \\
\text { (Marchwica, 2018) } \\
\text { - percussion instruments } \\
\text { (anvils, metal bell plates, } \\
\text { bass drum etc.; Adams, } \\
\text { 2010) } \\
\text { - choral, mono-rhythmic, } \\
\text { contourless in structure } \\
\text { (Adams, 2010) } \\
\text {-falling and rising pitch } \\
\text { contour (Reymore, 2018) }\end{array}$ & $\begin{array}{l}\text {-the instruments used by } \\
\text { Orcs (Young, 2007) } \\
\text { — the power and terror of } \\
\text { those who want to destroy } \\
\text { the world } \\
\text {-fear-evoking } \\
\text { - the threat of incoming war } \\
\text {-dread and malice (Adams, } \\
\text { 2010; Reymore, 2018) }\end{array}$ \\
\hline
\end{tabular}




$\begin{array}{ll}\text { The Ring } & \text { The Evil of the Ring } \\ \text { (26) } & (36 \text { ", 12), History of } \\ & \text { the Ring (49”, 14) }\end{array}$
the Ring $(49 ", 14)$

4

Hobbits (42) Shire Pensive Setting (24", 22), Shire Rural Setting (36", 20)

$5 \quad$ Men (32)
Elves (35)





The Fellowship

(14)

(48", 15), The Realm of Gondor $(41 ", 17)$

Lothlórien (44", 12), Rivendell (40", 9), Evenstar $(31 ", 14)$

The Fellowship of the Ring (30", 14)

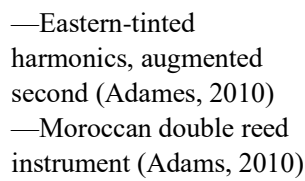

- folk leading instruments (the fiddle, the whistle, the flute, strings, or woodwinds)

-light orchestration creating simple, dance-like melodies in major mode (Marchwica, 2018; Young, 2007)

—French horns (Young, 2007) -brass instruments

(Adams, 2010)

-Nordic influences (i.e., Hardanger fiddle) in the Rohan Fanfare (Adams, 2010)

-chromatic harmonies

(Adams, 2010),

- minor mode

- use of exotic East Indian and African instruments (ney flute and sarangi) - echo effect

-women's choir singing in an antiphonal manner

(Marchwica, 2018)

-arpeggiated viola melody line imitating a harp part (Young, 2007)

- melody in minor mode -harmonization in major mode

—orchestration that evolves along with the plot (Adams, 2010) -aesthetics of prior age

(Adams, 2010)

-lore and lie that is the

Ring's nature, villainous inclinations represented in the Ring (Adams, 2010)

-home recollection; folksy, serene life (Adams, 2010),

-interest in worldly goods: food and drink; safety and friendship (Tolkien, 2002) -unconstrained joy, carefree fun (Marchwica, 2018)

- the former glory and the coming of the re-established kingdom

- Tolkien's description of the blowing of the horns of Rohan (Adams, 2010)

\author{
-unreal, dehumanized \\ world, beyond time and \\ reality (Marchwica, 2018) \\ - nostalgia for the bygone \\ greatness \\ - "neither sad, happy, \\ aggressive nor passive, but \\ aloof' (Adams, 2010, p. 51), \\ therefore uneasy, with \\ a touch of threat and mystery \\ - the stoutheartedness and \\ kindness of the members of \\ the Fellowship \\ -heroic and triumphant \\ (DePree, 2017)
}

Note. The numbers in parentheses indicate (1) the frequency of occurrence of a given musical motif in the study and (2) the length of the music piece (in seconds) encompassing the motif. 


\section{RESULTS}

Each question was analyzed separately. The first and second questions are analyzed in the Felt music-induced emotions section, and the third question is analyzed in the Associations section.

\section{Felt music-induced emotions}

To identify the music-induced emotions felt while listening to the LOTR music (Q1), we calculated the descriptive statistics. As music-induced emotions tend to have skewed distribution (Chełkowska-Zacharewicz, 2017), we used medians in the description below. The box-plots presented in Figure 1 confirm this tendency, showing the skewed distribution of the data. In the group listening to Good/Nature themes (the Good/Nature group) the scores were the lowest on the Being Moved and Sadness scales $(M e=3.00)$ and the highest on the Power scale $(M e=12.00)$. In the group listening to Evil themes (the Evil group) participants scored the lowest in Being Moved and Tenderness $(M e=3.00)$ and the highest in Wonder $(M e=10.00)$. The group listening to Ring motifs (the Ring group) had the lowest Joyful Activation, Tenderness, Being Moved, and Tension scores $(M e=4.00)$ and, similarly to the Evil group, the highest Wonder scores $(M e=10.00)$. The group listening to the Fellowship theme had similar scores as the Good/Nature group: the lowest on emotions such as Sadness, Being Moved, and Tension (in each case, $M e=3.00$ ) and the highest on the Power and Wonder scales $(M e=12.00)$. Score patterns for the motifs associated with characters from the Middle-earth differed slightly. While for the groups listening to Men and Hobbits themes (the Men group and the Hobbit group) the lowest scores were obtained on the Tension scale $(M e=3.00)$-for Hobbits, Sadness scores were low as well $(M e=3.00)$; the group listening to Elves themes (the Elves group) scored low on Being Moved $(M e=3.50)$. The highest scores for Elves and Men were obtained on Wonder ( $M e=11.50$ and $M e=11.00$, respectively) and Nostalgia ( $M e=11.00$ in both motif groups), while for Hobbits the scores were the highest on Tenderness $(M e=11.00)$ and Peacefulness $(M e=12.00)$.

To verify whether emotions experienced while listening to music differ across motif groups (Q2), we used the Kruskal-Wallis rank test with multiple comparisons of mean ranks. The results along with the indication of significant differences between the motif groups are presented in Table 2. Due to the online design of the study, some of the participants did not respond to several GEMSPL items. This resulted in different numbers of participants for particular motifs in different scales. Therefore, in Table 2, presenting the results of the test, the number of participants is given for each motif group in each scale. 


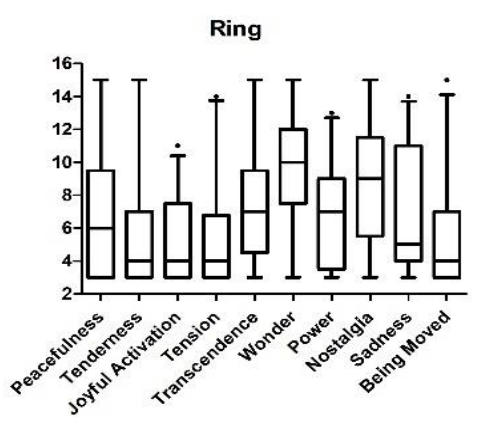

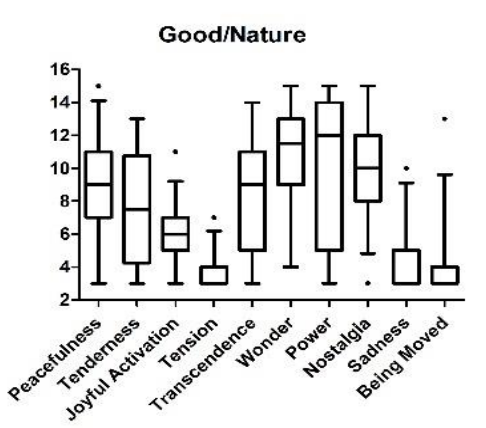

Elves

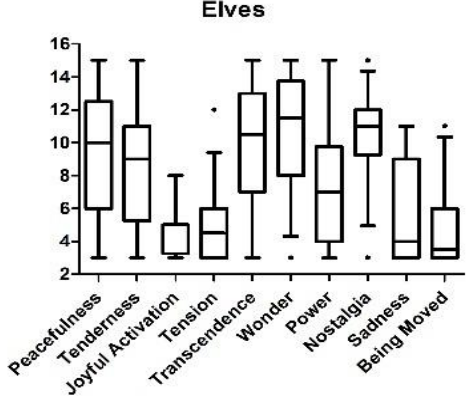

Hobbits

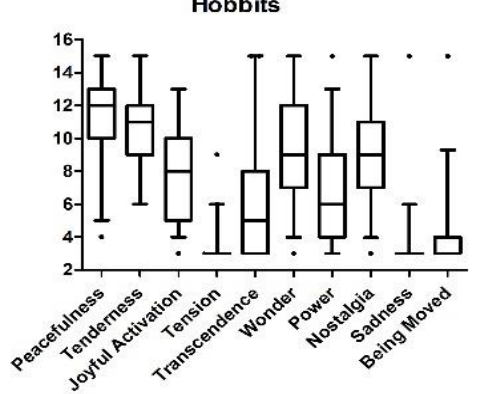

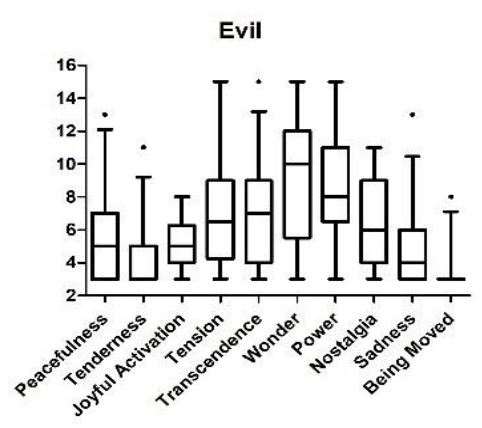

Men

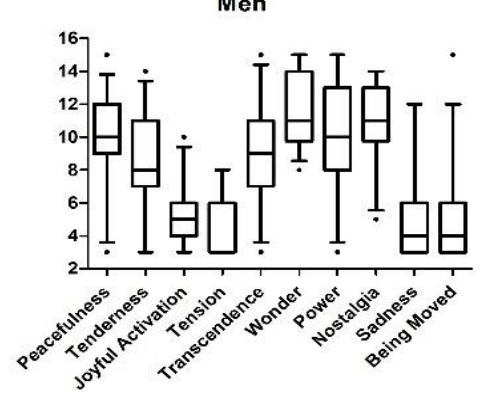

The Fellowship

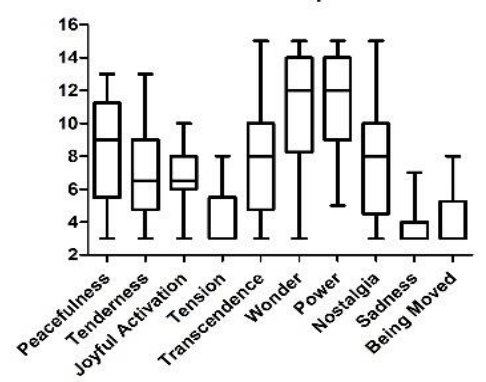

Figure 1. Box plots with median and 5-95 percentiles for GEMS-PL in 7 motif groups. 
Table 2. Results of the Kruskal-Wallis Rank Test for Seven Motif Groups

\begin{tabular}{|c|c|c|c|c|c|c|c|c|}
\hline & \multirow{2}{*}{$\begin{array}{c}H \\
(d f=6)\end{array}$} & \multicolumn{7}{|c|}{ Mean ranks } \\
\hline & & $\begin{array}{l}\text { Good/ } \\
\text { Nature }\end{array}$ & Elves & Hobbits & Ring & Men & Evil & $\begin{array}{l}\text { The } \\
\text { Fellowship }\end{array}$ \\
\hline Peacefulness & $63.113 * * *$ & $\begin{array}{c}108.73 \\
(N=37) \\
\mathrm{c}, \mathrm{f}\end{array}$ & $\begin{array}{c}121.39 \\
(N=33) \\
\mathrm{f}\end{array}$ & $\begin{array}{c}255.53 \\
(N=39) \\
\text { a, d }\end{array}$ & $\begin{array}{c}75.86 \\
(N=25) \\
\mathrm{c}, \mathrm{e}\end{array}$ & $\begin{array}{c}129.23 \\
(N=31) \\
\mathrm{d}, \mathrm{f}\end{array}$ & $\begin{array}{c}53.42 \\
(N=37) \\
\mathrm{a}, \mathrm{b}, \mathrm{c}, \mathrm{e}\end{array}$ & $\begin{array}{c}104.46 \\
(N=14)\end{array}$ \\
\hline Tenderness & $76.91 * * *$ & $\begin{array}{c}109.17 \\
(N=36) \\
\mathrm{c}\end{array}$ & $\begin{array}{c}124.02 \\
(N=32) \\
\mathrm{d}, \mathrm{f}\end{array}$ & $\begin{array}{c}162.31 \\
(N=39) \\
\mathrm{a}, \mathrm{d}, \mathrm{f}, \mathrm{g}\end{array}$ & $\begin{array}{c}73.04 \\
(N=25) \\
\mathrm{b}, \mathrm{c}\end{array}$ & $\begin{array}{c}122.40 \\
(N=31) \\
\mathrm{f}\end{array}$ & $\begin{array}{c}49.08 \\
(N=37) \\
\mathrm{a}, \mathrm{b}, \mathrm{c}, \mathrm{d}, \mathrm{e}\end{array}$ & $\begin{array}{c}95.71 \\
(N=14) \\
\mathrm{c}\end{array}$ \\
\hline Tension & $50.48 * * *$ & $\begin{array}{c}95.99 \\
(N=35) \\
\mathrm{f}\end{array}$ & $\begin{array}{c}115.31 \\
(N=32) \\
\mathrm{c}\end{array}$ & $\begin{array}{c}66.51 \\
(N=39) \\
\mathrm{b}, \mathrm{d}, \mathrm{f}\end{array}$ & $\begin{array}{c}119.96 \\
(N=24) \\
\mathrm{c}\end{array}$ & $\begin{array}{c}94.79 \\
(N=31) \\
\mathrm{f}\end{array}$ & $\begin{array}{c}156.07 \\
(N=36) \\
\mathrm{a}, \mathrm{c}, \mathrm{e}, \mathrm{g}\end{array}$ & $\begin{array}{c}91.89 \\
(N=14) \\
\mathrm{f}\end{array}$ \\
\hline Joyful Activation & $41.65 * * *$ & $\begin{array}{c}115.89 \\
(N=37)\end{array}$ & $\begin{array}{c}73.88 \\
(N=32) \\
\mathrm{c}, \mathrm{g}\end{array}$ & $\begin{array}{c}154.49 \\
(N=39) \\
\mathrm{b}, \mathrm{d}, \mathrm{e}, \mathrm{f}\end{array}$ & $\begin{array}{c}84.72 \\
(N=25) \\
\mathrm{c}\end{array}$ & $\begin{array}{c}96.61 \\
(N=31) \\
\mathrm{c}\end{array}$ & $\begin{array}{c}97.37 \\
(N=38) \\
\mathrm{c}\end{array}$ & $\begin{array}{c}139.00 \\
(N=14) \\
\mathrm{b}\end{array}$ \\
\hline Power & $34.03 * * *$ & $\begin{array}{c}131.49 \\
(N=37) \\
\mathrm{b}, \mathrm{c}\end{array}$ & $\begin{array}{c}84.64 \\
(N=32) \\
\mathrm{e}, \mathrm{g}\end{array}$ & $\begin{array}{c}83.00 \\
(N=39) \\
\text { a, e, g }\end{array}$ & $\begin{array}{c}83.54 \\
(N=25) \\
\text { e, } g\end{array}$ & $\begin{array}{c}135.48 \\
(N=31) \\
\mathrm{b}, \mathrm{c}, \mathrm{d}\end{array}$ & $\begin{array}{c}107.66 \\
(N=38)\end{array}$ & $\begin{array}{c}156.15 \\
(N=13) \\
\mathrm{b}, \mathrm{c}, \mathrm{d}\end{array}$ \\
\hline Wonder & $13.13 *$ & $\begin{array}{c}116.03 \\
(N=36)\end{array}$ & $\begin{array}{c}116.28 \\
(N=32)\end{array}$ & $\begin{array}{c}89.14 \\
(N=39)\end{array}$ & $\begin{array}{c}96.88 \\
(N=25)\end{array}$ & $\begin{array}{c}129.53 \\
(N=30)\end{array}$ & $\begin{array}{c}91.11 \\
(N=37)\end{array}$ & $\begin{array}{c}124.11 \\
(N=14)\end{array}$ \\
\hline Transcendence & $27.41 * * *$ & $\begin{array}{c}117.72 \\
(N=37)\end{array}$ & $\begin{array}{c}139.56 \\
(N=32) \\
\text { c, f }\end{array}$ & $\begin{array}{c}76.58 \\
(N=39) \\
\mathrm{b}, \mathrm{e}\end{array}$ & $\begin{array}{c}99.44 \\
(N=25)\end{array}$ & $\begin{array}{c}131.92 \\
(N=31) \\
\mathrm{c}\end{array}$ & $\begin{array}{c}90.30 \\
(N=37) \\
\mathrm{b}\end{array}$ & $\begin{array}{c}106.82 \\
(N=14)\end{array}$ \\
\hline Nostalgia & $51.59 * * *$ & $\begin{array}{c}120.84 \\
(N=37) \\
\text { f }\end{array}$ & $\begin{array}{c}139.31 \\
(N=32) \\
\text { f }\end{array}$ & $\begin{array}{c}103.71 \\
(N=38) \\
\mathrm{f}\end{array}$ & $\begin{array}{c}94.64 \\
(N=25)\end{array}$ & $\begin{array}{c}142.43 \\
(N=30) \\
\quad \mathrm{f}, \mathrm{g}\end{array}$ & $\begin{array}{c}54.89 \\
(N=37) \\
\mathrm{a}, \mathrm{b}, \mathrm{c}, \mathrm{e}\end{array}$ & $\begin{array}{c}79.85 \\
(N=13) \\
\mathrm{e}\end{array}$ \\
\hline Sadness & $31.97 * * *$ & $\begin{array}{c}93.69 \\
(N=37) \\
\mathrm{d}\end{array}$ & $\begin{array}{c}123.50 \\
(N=31) \\
\mathrm{c}\end{array}$ & $\begin{array}{c}77.99 \\
(N=39) \\
\mathrm{b}, \mathrm{d}\end{array}$ & $\begin{array}{c}147.94 \\
(N=25) \\
\text { a, c, g }\end{array}$ & $\begin{array}{c}116.08 \\
(N=31)\end{array}$ & $\begin{array}{c}111.92 \\
(N=36)\end{array}$ & $\begin{array}{c}80.61 \\
(N=14) \\
\mathrm{d}\end{array}$ \\
\hline Being Moved & $17.29 * *$ & $\begin{array}{c}100.01 \\
(N=36)\end{array}$ & $\begin{array}{c}118.88 \\
(N=32)\end{array}$ & $\begin{array}{c}106.03 \\
(N=38)\end{array}$ & $\begin{array}{c}124.50 \\
(N=25)\end{array}$ & $\begin{array}{c}122.40 \\
(N=31)\end{array}$ & $\begin{array}{c}78.68 \\
(N=37)\end{array}$ & $\begin{array}{c}109.96 \\
(N=14)\end{array}$ \\
\hline Column name & & A & B & $\mathrm{C}$ & $\mathrm{D}$ & $\mathrm{E}$ & $\mathrm{F}$ & G \\
\hline
\end{tabular}

Note. $H$-Kruskal-Wallis test, $d f$ - degrees of freedom, $N$-number of observations, a-g - significant differences in multiple comparisons tests of mean ranks $(p<.05){ }^{*} p<.05, * * p<.01,{ }^{* * *} p<.001$. 
The Kruskal-Wallis test showed significant differences in all GEMS-PL scales. The multiple comparisons tests of mean ranks performed for each scale showed differences between the compared groups for all scales except Being Moved and Wonder.

While listening to the Evil group of motifs, the subjects felt a lower level of Peacefulness in comparison to the Ring and the Fellowship groups, and while listening to Hobbits themes they reported a higher level of Peacefulness than in the case of Evil, the Ring, and Good/Nature themes. Tenderness was lower in the Evil group in all comparisons except the Ring and the Fellowship groups. Subjects from the Hobbits group scored higher on Tenderness compared to the Good/Nature, Ring, Evil, and Fellowship groups. The Ring group scored lower on Tenderness in comparison with the Elves and Hobbits groups. Tension scores were higher in the Evil group in comparison to all others except the Elves and the Ring groups. In the Hobbits group, Tension was lower than in the Elves, Ring, and Evil groups. Joyful Activation was higher in the Hobbits group in comparison with all other groups but Good/Nature and the Fellowship. The Elves group had a lower level of Joyful Activation in comparison with the Hobbits and Fellowship groups. In the Fellowship group, Power was higher than in the Hobbits, Ring, and Men groups. A lower level of Power was found in the Elves group compared to the Good/Nature, Men, and Fellowship groups; Power was also lower in the Hobbits group than in the Good/Nature, Men, and Fellowship groups, and lower in the Ring group than in the Men and Fellowship groups. For Transcendence, higher scores were obtained in the Elves group in comparison with Hobbits and Evil; Transcendence scores in the Men group were higher than in the Hobbits group. Sadness scores were higher in the Ring group than in the Good/Nature, Hobbits, and Fellowship groups. Sadness was lower in the Hobbits group compared to the Ring and Elves groups. In the case of the Nostalgia scale, lower scores were obtained in the Evil group compared to all the other groups except those that listened to the Ring and the Fellowship motifs. The Men group scored higher in Nostalgia than the Fellowship group.

\section{Associations}

We obtained 388 associations, ranging from 1 to 4 between subjects $(M=1.46)$. To investigate Q3, 388 subjects' answers were assessed by two peer judges - psychologists. To ensure objectivity and avoid bias, the judges followed a three-step procedure: (1) independently creating categories encompassing participants' responses and assigning each answer to the appropriate category, 
(2) discussing any differences between the created categories and the assignment of responses, and (3) creating the final categories and establishing response assignments upon mutual agreement. The categories encompass associations with films (LOTR, The Hobbit, and others; see Table A1 in Appendix) and non-film associations (see Table A2 in Appendix).

Out of 56 associations with films, the most popular ones were those with the LOTR trilogy (Table A1 in Appendix). The association appeared mostly in the Hobbits theme group. The category "other movies" included both general answers such as "movie about the Middle Ages," "Irish movie," "historical film," or "a good movie," and specific responses with titles such as Braveheart, Pocahontas, Avatar, or Star Trek. The third group of film associations were those with The Hobbit movie.

The 332 non-film associations reported by the participants (Table A2 in Appendix) included ideas (131 answers, 39\%), objects (99 answers, 30\%), emotions (52 answers, 16\%), states of mind (27 answers, $8 \%$ ), space or place (14 answers, 4\%), supernatural elements (6 answers, 2\%), and characters (3 answers, 1\%). Table A2 in Appendix presents all general associations (ideas, objects, states of mind, emotions, space, characters, and supernatural elements) and the respective specific associations (i.e., victory, nature, hope, and positive emotions), as well as subjects' sample answers.

Some differences could be observed among participants presented with music themes from different groups. Subjects listening to Good/Nature themes were likely to report associations with ideas (28 answers, 55\%), objects (10 answers, $20 \%$ ), states of mind ( 5 answers, $10 \%$ ), emotions ( 5 answers, 10\%), and space (3 answers, 6\%). Listening to Elves theme music came with connotations of ideas (27 answers, 44\%), objects (12 answers, 20\%), emotions ( 7 answers, $11 \%$ ), space ( 5 answers, $8 \%$ ), supernatural elements ( 5 answers, $8 \%$ ), characters ( 3 answers, $5 \%$ ), and state of mind ( 2 answers, $3 \%$ ). In the case of Hobbits music themes, the most frequent associations were objects (21 answers, 45\%) and emotions (16 answers, 34\%). The Ring themes were mostly associated with ideas (16 answers, 41\%) and emotions (9 answers, 23\%). Evil music themes were generally associated with ideas (20 answers, 34\%), objects ( 24 answers, $41 \%$ ), and emotions (10 answers, 17\%). For the themes of Men, the most frequent associations were ideas (23 answers, 40\%) and objects (21 answers, 37\%). The Fellowship of the Ring motifs correlated mostly with thoughts of ideas (13 answers, 68\%). 


\section{DISCUSSION}

The LOTR soundtrack is an excellent example of leitmotif use in film music. Music symbols that included certain instruments, scales, timbres, etc. were used by Howard Shore to vividly paint the whole movie scenery. Our study set out to analyze the emotional reactions and associations that may appear while listening to the LOTR music.

Regarding music-induced emotions and associations that appeared while listening to the LOTR soundtrack, we observed that participants felt musicinduced emotions and had associations that were related to the symbolic characteristics of music themes.

The most distinctive differences in music-induced emotions appeared in the group listening to Hobbits motifs than in other groups. The subjects in this group scored high on Peacefulness, Tenderness, and Joyful Activation, which may relate to the carefree joy (Marchwica, 2018) and the feeling of safety (Adams, 2010) that characterized the movie characters in question. The low Tension and Sadness scores also seem to be in line with Hobbits' lifestyle (Tolkien, 2002) and their serene nature (Adams, 2010). The lower Transcendence scores may mirror the rustic life with the praise of worldly goods (Adams, 2010). The associations that came to subjects' minds included mostly object of nature and positive emotions (see Table A2 in Appendix). This shows the vividness of Shore's hobbits leitmotifs, which were created not only to musically describe hobbits life and unconstrained joy (Marchwica, 2018), but also their habitat in a very natural land of meadows, fields, and gardens (Tolkien, 2002).

A number of significant differences were observed also for subjects listening to Evil motifs in comparison to other groups. Their higher Tension and lower Peacefulness and Tenderness may relate to the fear, terror, and threat that are illustrated in the music. The dread and threat of Evil music motifs (Reymore, 2018), as well as the illustration of incoming war (Adams, 2010), were also mirrored in associations, as participants listening to them had thoughts of negative emotions, danger, battle, and something explicitly evil (see Table A2 in Appendix). However, other associations such as power, victory, and majesty, or nature were also noted and did not relate to Shore's or Adams's (2010) direct description. These associations were not mirrored in music-induced emotions, as the feeling of Power was not strong in this group.

Subjects' answers on associations while listening to the Ring group of motifs were related to majesty, power, and danger, as well as to negative emotions and states of mind such as reflection or anticipation (see Table A2 in Appendix). 
They were in line with Shore's idea of musically illustrating the Ring's mysterious character, the ability to control minds of others, its association with evil (Young, 2007), and villainous inclinations (Adams, 2010). However, the listeners' music emotions were somehow contradictory to these associations, as their Sadness score was higher and the Power score was lower than in other music groups. Power in GEMS (Zentner et al., 2008) relates to victory and triumph, while in the Ring motifs the power was rather related to danger and evil strength (Adams, 2010). Therefore, another possible explanation involves sadness as the listener's complementary reaction to the power perceived in music rather than as a reflection of his or her feelings of power.

While listening to the Elves motifs, participants indicated that they thought of ideas such as mystery, majesty, beauty, and good, objects connected with nature, mostly positive emotions, space and places such as a castle, and supernatural elements of magic and fantasy (see Table A2 in Appendix). Participants also explicitly reported an association with the elf characters. These unique associations, different than others because they involve supernatural elements and the notion of elves, reflect Shore's idea of musically painting the unreal, dehumanized elvish world, beyond time and reality (Marchwica, 2018). At the same time, there were strong emotional reactions in the case of Transcendence and weak ones in the case of Joyful Activation, which is consistent with the characteristics of elves, bringing to mind nostalgia, threat, and the mystery of the wise and dignified race from Tolkien's Middle-earth (Adams, 2010).

The last three groups scored similarly high on Power compared to other groups. Men, Fellowship, and Good/Nature music listeners did not obtain other strong or distinctive results regarding music-induced emotions. Although in all these groups there appeared thoughts connected with victory, the subjects associated music motifs from these groups differently. The listeners of Good/Nature motifs reported associations with ideas such as victory, majesty, and power, as well as objects connected with nature. They also thought of space, hope, and positive emotions (see Table A2 in Appendix). Such associations are in line with the plot of the LOTR, where Eagles or Ents join the fight in the battle scenes (Adams, 2010) and help to eventually defeat the evil (Tolkien, 2002).

Participants listening to the Men group of motifs indicated thoughts such as ideas of victory and journey, objects connected with nature and battle, and states of mind such as reflection and positive emotions (see Table A2 in Appendix). The results show strong relations to the intentions of the race of Men in The Lord of the Rings (Tolkien, 2002) and to their deeds that led to the post-battle re-estab- 
lishment of the once fallen kingdom - something that Shore illustrated in his music (Adams, 2010).

The associations reported by participants listening to the Fellowship group of motifs encompassed mostly ideas of victory, power, and journey, as well as nature and battle-related objects, hope, and positive emotions (see Table A2 in Appendix). Thus, they reflected Shore's illustration of the Fellowship, its mission of changing the fate of Middle-earth (Tolkien, 2002), its power in the union of Middle-earth's stouthearted people, and their journey that ended in the defeat of the title Lord of the Rings (Adams, 2010).

As presented, while listening to the chosen music motifs, participants felt emotions and associations mostly consistent with Howard Shore's intentions (Adams, 2010). The results obtained in this study show how much of an impact the music from The Lord of the Rings has on listeners, being a very good example of the possibilities that music offers to film works.

However, it must be noted that some of the symbols utilized in the LOTR music may be more vivid for Polish listeners (as representatives of Western music listeners). For example, rhythmic, lively music in major mode indicates joy and happiness (Juslin \& Sloboda 2012), which may have resulted in a stronger distinctiveness of listeners' emotions and associations in the case of the Hobbits motif group in comparison to other groups. Similarly, the minor mode and dissonances or lower pitch may bring to mind the expression of fear (Juslin \& Sloboda, 2013), which might have resulted in quite distinctive emotional responses in the case of the Evil music motifs listeners. Possibly, the music-induced emotions that the subjects felt were not as strong as the emotions that they perceived in LOTR music. The latter, however, were not measured in this study. This suggests an interesting future direction for research where a clear distinction between felt and perceived emotions would be made; the two types of music emotions could be compared and measured.

\section{Limitations and future research}

The sample in the study was not very large, and the study design did not allow us to ensure an equal number of participants in all motif groups. As the music was selected randomly by the software, different motif groups were presented unevenly, the number of listeners in a group ranging from 14 to 42 . The results are therefore limited and should be interpreted carefully; further analysis is needed, with a larger sample and an equal count of participants in motif groups. 
For the purpose of the study, we included the rating of familiarity with the LOTR music and movies. The question about the familiarity was asked at the very end of the procedure in order to avoid bias among participants. Familiarity level was average in the case of the movies and low in the case of the music. These results, along with the fact that the music evoked relatively few associations strictly related to the LOTR movies, allowed us to assume that the results were not mainly influenced by the participants' knowledge of the plot. Nevertheless, the results for emotion scales as well as for associations may have been biased by this knowledge and should be interpreted with caution. Therefore, future research should control for the familiarity of the LOTR movies. Unfortunately, due to the small sample size, this kind of analysis would not be robust for the data set collected in the present study.

\section{REFERENCES}

Adams, D. (2010). The music of The Lord of the Rings films. Van Nuys: Alfred Publisher.

Bolivar, V. J., Cohen, A. J., \& Fentress, J. C. (1994). Semantic and formal congruency in music and motion pictures: Effects on the interpretation of visual action. Psychomusicology, 13, 28-59.

Boltz, M. G. (2001). Musical soundtracks as a schematic influence on the cognitive processing of filmed events. Music Perception, 18, 427-454.

Boltz, M. G. (2004). The cognitive processing of film and musical soundtracks. Memory \& Cognition, 32, 1194-1205.

Boltz, M. G., Schulkind, M., \& Kantra, S. (1991). Effects of background music on the remembering of filmed events. Memory \& Cognition, 19, 593-606.

Bordwell, D., \& Thompson, K. (2008) Film art: An introduction ( $8^{\text {th }}$ ed.). Boston, MA, US: McGraw Hill.

Chattah, J. (2006). Semiotics, pragmatics, and metaphor in film music analysis. Retrieved from http://purl.flvc.org/fsu/fd/FSU_migr_etd-3874

Chełkowska-Zacharewicz, M. (2017). Reagowanie na muzykę-afektywne podstawy i rola kontekstu poznawczego [Reacting to music: The affective basis and the role of the cognitive context] (Unpublished doctoral dissertation). University of Silesia, Katowice, Poland.

Chełkowska-Zacharewicz, M., \& Janowski, M. (in review). Polish adaptation of Geneva Emotional Music Scale (GEMS) - factor structure and reliability.

Chełkowska-Zacharewicz, M., \& Janowski, M. (2016). Polska adaptacja Geneva Emotional Music Scale (GEMS) - badania wstępne. Polskie Pismo Muzykoterapeutyczne, 3, 44-63.

Cohen, A. J. (1993). Associationism and musical soundtrack phenomena. Contemporary Music Review, 9, 163-178.

Cohen, A. J. (1998). The functions of music in multimedia: A cognitive approach. In Proceedings of the Fifth International Conference on Music Perception and Cognition (pp. 13-20). Seoul: Western Music Research Institute, Seoul National University. 
Cohen, A. J. (2010). Music as a source of emotion in film. In J. A. Sloboda \& P. N. Juslin (Eds.), Handbook of music and emotion. Theory, research, application (pp. 879-908). Oxford: Oxford University Press.

Cohen, A. J. (2014). Film music from the perspective of cognitive science. In D. Neumeyer (Ed.), The Oxford handbook of film music studies (pp. 96-130). Oxford: Oxford University Press.

Coutinho, E., \& Scherer, K. R. (2017). Introducing the Geneva Music-Induced Affect Checklist (GEMIAC): A brief instrument for the rapid assessment of musically induced emotions. Music Perception: An Interdisciplinary Journal, 34(4), 371-386.

Davies, S. (2010). Emotions expressed and aroused by music. Philosophical perspectives. In P. N. Juslin \& J. A. Sloboda (Eds.), Handbook of music and emotion: Theory, research, applications (pp. 15-43). New York, NY, US: Oxford University Press.

DePree, K. M. (2017). Cue the music: Music in movies. The Research and Scholarship Symposium, 5, 1-25.

Gabrielsson, A. (2001). Emotion perceived and emotion felt: Same or different? Musicae Scientiae, Special Issue, 123-147.

Gabrielsson, A. (2010). Strong experiences with music. In P. N. Juslin \& J. A. Sloboda (Eds.), Handbook of music and emotion: Theory, research, applications (pp. 547-574). New York, NY, US: Oxford University Press.

Green, J. (2010). Understanding the score: Film music communicating to and influencing the audience. The Journal of Aesthetic Education, 44(4), 81-94.

Hagen, E. (1971). Scoring for films: A complete text (vol. 1). New York, NY, US: Criterion Music Corp.

Hanning, B. (2002). Concise history of western music. New York, NY, US: W. W. Norton \& Co.

Huron, D. (2007). Sweet anticipation: Music and the psychology of expectation. Cambridge, MA, US: The MIT Press.

Juslin, P. N. (2013a). What does music express? Basic emotions and beyond. Frontiers in Psychology, 4, 596.

Juslin, P. N. (2013b). From everyday emotions to aesthetic emotions: Towards a unified theory of musical emotions. Physics of Life Reviews, 10(3), 235-266.

Juslin, P. N., Harmat, L., \& Eerola, T. (2014). What makes music emotionally significant? Exploring the underlying mechanisms. Psychology of Music, 42(4), 599-623.

Juslin, P. N., Liljeström, S., Västfjäll, D., Barradas, G., \& Silva, A. (2008). An experience sampling study of emotional reactions to music: Listener, music, and situation. Emotion, 8(5), 668-683.

Juslin, P. N., \& Sloboda, J. A. (2010). Handbook of music and emotion: Theory, research, and applications. New York, NY, US: Oxford University Press.

Juslin, P. N., \& Sloboda, J. A. (2013). Music and emotion. In D. Deutsch (Ed.), The psychology of music (pp. 583-645). San Diego, CA, US: Elsevier Academic Press.

Juslin, P. N., \& Västfjäll, D. (2008). Emotional responses to music: The need to consider underlying mechanisms. Behavioral and Brain Sciences, 31(5), 559-575; discussion 575-621.

Kallinen, K., \& Ravaja, N. (2006). Emotion perceived and emotion felt: Same and different. Musicae Scientiae, 10(2), 191-213.

Konečni, V. J. (2008). A skeptical position on "musical emotions" and an alternative proposal. Behavioral and Brain Sciences, 31, 582-584.

Marchwica, W. M. (2018). Musical scenery: Utopia vs. arcadia in The Lord of the Rings (dir. Peter Jackson). Musica Iagellonica, 9, 127-142.

Marshall, S. K., \& Cohen, A. J. (1988). Effects of musical soundtracks on attitudes toward animated geometric figures. Music Perception: An Interdisciplinary Journal, 6(1), 95-112. 
Meyer, L. B. (1974). Emocja i znaczenie w muzyce [Emotion and meaning in music]. Kraków: Polskie Wydawnictwo Muzyczne.

Nagari, B. (2015). Music as image: Analytical psychology and music in film. New York, NY, US: Routledge.

Neumeyer, D. (Ed.) (2013). The Oxford handbook of film music studies. Oxford: Oxford University Press.

Otero, T. P. (2015). Composition, variation and functions of the leitmotiv in the universe Indiana Jones. Revista de Comunicación de la SEECI, 19(37), 238-267.

Prendergast, R. M. (1992). Film music. A neglected art: A critical study of film music in films. New York, NY, US: W. W. Norton \& Company.

Provenzano, C. (2008). Towards an aesthetic of film music: Musicology meets the film soundtrack. Music Reference Services Quarterly, 10, 79-94.

Reymore, L. (2018). Musical expression and embodiment: Fear, threat, and danger in the music of The Lord of the Rings. In R. Parncutt \& S. Sattmann (Eds.), Proceedings of ICMPC15/ ESCOM10. Graz, Austria: Centre for Systematic Musicology, University of Graz.

Richards, M. (2016). Film music themes: Analysis and corpus study. Music Theory Online - A Journal of the Society for Music Theory, 22(1), 1-27.

Saarikallio, S. (2011). Music as emotional self-regulation throughout adulthood. Psychology of Music, 39(3), 307-327.

Sebeok, T. (2001). Signs: An introduction to semiotics ( $2^{\text {nd }}$ ed.). Toronto: University of Toronto Press.

Tan, S. L., Spackman, M. P., \& Bezdek, M. A. (2007). Viewers' interpretation of film characters' emotions: Effect of presenting film music before and after a character is shown. Music Perception, 25(2), 135-152.

Tan, S. L., Spackman, M. P., \& Wakefield, E. M. (2017). The effects of diegetic and nondiegetic music on viewers' interpretation of a film scene. Music Perception, 34(5), 135-152.

Thayer, J., \& Levenson, R. (1983). Effects of music on psychophysiological responses to a stressful film. Psychomusicology, 3, 44-54.

Tolkien, J. R. R. (2002). Władca Pierścieni. T. 1: Drużyna Pierścienia [The Lord of the Rings. Vol. 1: The Fellowship of the Ring] (Maria Skibniewska, Trans.). Warsaw: Warszawskie Wydawnictwo Literackie MUZA SA.

Västfjäll, D. (2001). Emotion induction through music: A review of the musical mood induction procedure. Musicae Scientiae, 5(1 suppl), 173-211.

Vilaro, A., \& Orero, P. (2013). Leitmotif in audio description: Anchoring information to optimise retrieval. International Journal of Humanities and Social Science, 3(5), 56-64.

Walus, B. P. (2012). A new modular approach to the composition of film music. Retrieved from https://digital.library.adelaide.edu.au/dspace/bitstream/2440/84425/8/02wholev1.pdf.

White, D. (2016). Middle-earth music: The sonic inhabitation of a fantasy world. Participations: Journal of Audience and Reception Studies, 13(1), 488-511.

Whittall, A. (2001). Leitmotif. In The new grove dictionary of music and musicians ( $2^{\text {nd }}$ ed., vol. 14, pp. 527-530). London: Macmillan.

Young, M. D. (2007). Projecting Tolkien's musical worlds: A study of musical affect in Howard Shore's soundtrack to Lord of the Rings. Saarbrücken: AV Akademikerverlag.

Zentner, M., Grandjean, D., \& Scherer, K. R. (2008). Emotions evoked by the sound of music: Characterization, classification, and measurement. Emotion, 8(4), 494-521. 
APPENDIX

Table A1. Film Associations with the LOTR Soundtrack

\begin{tabular}{|c|c|c|c|c|c|c|c|c|}
\hline \multirow[b]{2}{*}{$\begin{array}{l}\text { Film } \\
\text { association }\end{array}$} & \multicolumn{8}{|c|}{ Motif group } \\
\hline & $\begin{array}{l}\text { Good/ } \\
\text { Nature }\end{array}$ & Elves & Hobbits & Ring & Men & Evil & $\begin{array}{l}\text { Fellowship } \\
\text { of the Ring }\end{array}$ & Total \\
\hline $\begin{array}{l}\text { The Lord } \\
\text { of the Rings }\end{array}$ & 2 & 4 & 10 & 4 & 4 & 5 & 3 & 32 \\
\hline $\begin{array}{l}\text { Other } \\
\text { movies }\end{array}$ & 4 & 2 & 2 & 2 & 5 & 1 & 2 & 18 \\
\hline The Hobbit & 0 & 0 & 5 & 0 & 1 & 0 & 0 & 6 \\
\hline Total & 6 & 6 & 17 & 6 & 10 & 6 & 5 & 56 \\
\hline
\end{tabular}

Table A2. Non-Film Associations with the LOTR Soundtrack

\begin{tabular}{|c|c|c|c|}
\hline \multirow{2}{*}{ Motif group } & \multicolumn{3}{|c|}{ Categorization level } \\
\hline & General & Specific & Detailed (Sample answers) \\
\hline & & $\begin{array}{l}\text { Glory/victory } \\
(7 ; 25 \%)\end{array}$ & $\begin{array}{l}\text { „glory," "victory," "overcoming } \\
\text { obstacles" }\end{array}$ \\
\hline & & $\begin{array}{l}\text { Majesty } \\
(10 ; 36 \%)\end{array}$ & $\begin{array}{l}\text { "sublime moment," "sublimity," } \\
\text { "something sublime, solemn" }\end{array}$ \\
\hline & & Power $(4 ; 14 \%)$ & $\begin{array}{l}\text { "power and greatness," "power and } \\
\text { energy" }\end{array}$ \\
\hline & & Journey $(4 ; 14 \%)$ & $\begin{array}{l}\text { "journey," "exploring new territories," } \\
\text { "discovering a hidden land" }\end{array}$ \\
\hline & & $\begin{array}{l}\text { Adventure } \\
(1 ; 4 \%)\end{array}$ & "adventure" \\
\hline & & Beauty $(1 ; 4 \%)$ & "something beautiful" \\
\hline & Idea $(28 ; 51 \%)$ & Parting $(1 ; 4 \%)$ & $\begin{array}{l}\text { "people saying goodbye to a departing } \\
\text { ship" }\end{array}$ \\
\hline & & Nature $(8 ; 80 \%)$ & $\begin{array}{l}\text { "horses galloping in boundless green } \\
\text { valleys,", "mountains," "clouds" }\end{array}$ \\
\hline & Object $(10 ; 10 \%)$ & $\begin{array}{l}\text { Battle/battle } \\
\text { objects }(2 ; 20 \%)\end{array}$ & $\begin{array}{l}\text { "a song before the battle," "war is over," } \\
\text { getting ready for a battle" }\end{array}$ \\
\hline & & Hope $(2 ; 40 \%)$ & "hope," "someone finds hope" \\
\hline & & $\begin{array}{l}\text { Reflection } \\
(2 ; 40 \%)\end{array}$ & "reflection" \\
\hline & $\begin{array}{l}\text { State of mind } \\
(5 ; 10 \%)\end{array}$ & $\begin{array}{l}\text { Anticipation } \\
(1 ; 20 \%)\end{array}$ & "waiting for something important" \\
\hline & & $\begin{array}{l}\text { Positive emotion } \\
(3 ; 60 \%)\end{array}$ & $\begin{array}{l}\text { "a very positive moment," "serenity," } \\
\text { "relaxation" }\end{array}$ \\
\hline & $\begin{array}{l}\text { Emotion } \\
(5 ; 10 \%)\end{array}$ & $\begin{array}{l}\text { Negative emotion } \\
(2 ; 40 \%)\end{array}$ & $\begin{array}{l}\text { "anxiety," "sad life events," "hivers and } \\
\text { nervousness" }\end{array}$ \\
\hline $\begin{array}{l}\text { Good/Nature } \\
(51,100 \%)\end{array}$ & Space $(3 ; 6 \%)$ & Space $(3 ; 100 \%)$ & $\begin{array}{l}\text { "space," "the world from a bird's-eye } \\
\text { view" }\end{array}$ \\
\hline
\end{tabular}




\begin{tabular}{|c|c|c|c|}
\hline & & $\begin{array}{l}\text { Glory/victory } \\
(2 ; 7 \%)\end{array}$ & "victory" \\
\hline & & Majesty $(5 ; 19 \%)$ & “sublimity," "grandeur" \\
\hline & & Power $(3 ; 11 \%)$ & "power," "feeling of inner power" \\
\hline & & Journey $(1 ; 4 \%)$ & "journey beyond the horizon" \\
\hline & & Danger $(3 ; 11 \%)$ & "danger and threat" \\
\hline & & Beauty $(4 ; 15 \%)$ & "beauty," "beauty of the world" \\
\hline & & Mystery $(5 ; 19 \%)$ & "mystery," "something mysterious" \\
\hline & Idea $(27 ; 44 \%)$ & Good $(4,15 \%)$ & "triumph of the good" \\
\hline & Elves $(3 ; 5 \%)$ & Elves $(3 ; 100 \%)$ & "Elf," "elves" \\
\hline & & Nature $(9 ; 75 \%)$ & $\begin{array}{l}\text { "sailing on a ship in the far sea," } \\
\text { "blooming flowers," "green mountains," } \\
\text { "flying birds" }\end{array}$ \\
\hline & Object $(12 ; 20 \%)$ & $\begin{array}{l}\text { Battle/battle } \\
\text { objects }(3 ; 25 \%)\end{array}$ & "battle with oneself" \\
\hline & & $\begin{array}{l}\text { Reflection } \\
(1 ; 50 \%) \\
\end{array}$ & "reflection that one needs to be strong" \\
\hline & $\begin{array}{l}\text { State of mind } \\
(2 ; 3 \%)\end{array}$ & $\begin{array}{l}\text { Anticipation } \\
(1 ; 50 \%)\end{array}$ & "sort of anticipation" \\
\hline & & $\begin{array}{l}\text { Positive emotion } \\
(5 ; 71 \%)\end{array}$ & $\begin{array}{l}\text { "happiness," "endless happiness," } \\
\text { "excitement" }\end{array}$ \\
\hline & $\begin{array}{l}\text { Emotion } \\
(7 ; 11 \%)\end{array}$ & $\begin{array}{l}\text { Negative emotion } \\
(2 ; 29 \%)\end{array}$ & "a sad moment" \\
\hline & Supernatural & Magic $(3 ; 60 \%)$ & "magic," "dark magic practice" \\
\hline & $(5 ; 8 \%)$ & Fantasy $(2 ; 40 \%)$ & "fantasy," "unreal world" \\
\hline & & Space $(2 ; 40 \%)$ & $\begin{array}{l}\text { "gliding in the vast sky", "great space, } \\
\text { void" }\end{array}$ \\
\hline \multirow[t]{8}{*}{ Elves $(61,100 \%)$} & Space $(5 ; 8 \%)$ & Castle $(3 ; 60 \%)$ & "castle," "castle in the mountains" \\
\hline & & Journey $(1 ; 25 \%)$ & "journey" \\
\hline & Idea $(4 ; 9 \%)$ & $\begin{array}{l}\text { Adventure } \\
(3 ; 75 \%)\end{array}$ & "adventure" \\
\hline & & Nature $(19 ; 90 \%)$ & $\begin{array}{l}\text { "meadows," "flower-smelling meadows," } \\
\text { "great meadows," "nature," "mountains" }\end{array}$ \\
\hline & Object $(21 ; 45 \%)$ & Orchestra $(2 ; 10 \%)$ & "instruments" \\
\hline & & Hope $(1 ; 20 \%)$ & "hope" \\
\hline & $\begin{array}{l}\text { State of mind } \\
(5 ; 11 \%)\end{array}$ & $\begin{array}{l}\text { Reflection } \\
(4 ; 80 \%)\end{array}$ & $\begin{array}{l}\text { "encourages me to reflect on some } \\
\text { issues," "reflection" }\end{array}$ \\
\hline & $\begin{array}{l}\text { Emotion } \\
(16 ; 34 \%)\end{array}$ & $\begin{array}{l}\text { Positive emotion } \\
(16 ; 100 \%)\end{array}$ & $\begin{array}{l}\text { "general peace," "cheerful moments," } \\
\text { "optimism," "sheer joy," "relaxation" }\end{array}$ \\
\hline $\begin{array}{l}\text { Hobbits } \\
(47,100 \%)\end{array}$ & $\begin{array}{l}\text { Supernatural } \\
(1 ; 2 \%)\end{array}$ & Magic $(1 ; 100 \%)$ & "magic" \\
\hline
\end{tabular}




\begin{tabular}{|c|c|c|c|}
\hline & & $\begin{array}{l}\text { Glory/victory } \\
(2 ; 13 \%)\end{array}$ & "victorious battle" \\
\hline & & Majesty $(4 ; 25 \%)$ & "majesty" \\
\hline & & Power $(3 ; 19 \%)$ & “power” \\
\hline & & Danger $(3 ; 19 \%)$ & "something dangerous approaching" \\
\hline & & Parting $(2 ; 13 \%)$ & 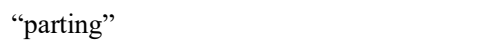 \\
\hline & Idea $(16 ; 41 \%)$ & Evil $(2 ; 13 \%)$ & "evil general at war" \\
\hline & & Nature $(4 ; 57 \%)$ & $\begin{array}{l}\text { "a ship swimming in a turbulent ocean," } \\
\text { "desert lands" }\end{array}$ \\
\hline & & $\begin{array}{l}\text { Battle/battle } \\
\text { objects }(2 ; 29 \%)\end{array}$ & "cruel battle" \\
\hline & Object $(7 ; 18 \%)$ & $\begin{array}{l}\text { Orchestra } \\
(1 ; 14 \%)\end{array}$ & "orchestral concert" \\
\hline & & Hope $(1 ; 17 \%)$ & "ray of hope" \\
\hline & & $\begin{array}{l}\text { Reflection } \\
(3 ; 50 \%)\end{array}$ & "reflective music" \\
\hline & $\begin{array}{l}\text { State of mind } \\
(6 ; 15 \%)\end{array}$ & $\begin{array}{l}\text { Anticipation } \\
(2 ; 33 \%)\end{array}$ & "anticipating something big" \\
\hline & & $\begin{array}{l}\text { Positive emotion } \\
(2 ; 22 \%)\end{array}$ & "peace," “calmness" \\
\hline & $\begin{array}{l}\text { Emotion } \\
(9 ; 23 \%)\end{array}$ & $\begin{array}{l}\text { Negative emotion } \\
(7 ; 78 \%)\end{array}$ & $\begin{array}{l}\text { "private matter that is very unpleasant to } \\
\text { me," "fear," "tension" }\end{array}$ \\
\hline \multirow[t]{16}{*}{ Ring $(39,100 \%)$} & Space $(1 ; 3 \%)$ & Space $(1 ; 100 \%)$ & "big, wide spaces in nature" \\
\hline & & $\begin{array}{l}\text { Glory/victory } \\
(8 ; 35 \%)\end{array}$ & "victory" \\
\hline & & Majesty $(2 ; 9 \%)$ & "majestic music" \\
\hline & & Power $(3 ; 13 \%)$ & “power” \\
\hline & & Journey $(5 ; 22 \%)$ & $\begin{array}{l}\text { "journey with companions," "end of } \\
\text { a journey" }\end{array}$ \\
\hline & & Adventure $(2 ; 9 \%)$ & "heading for adventure" \\
\hline & & Mystery $(1 ; 4 \%)$ & “mysterious landscapes" \\
\hline & Idea $(23 ; 40 \%)$ & Parting $(2 ; 9 \%)$ & "parting and farewell" \\
\hline & & Nature $(9 ; 43 \%)$ & $\begin{array}{l}\text { "mustang herd in full gallop," "meadow," } \\
\text { "nature," "sea" }\end{array}$ \\
\hline & & $\begin{array}{l}\text { Battle/battle } \\
\text { objects }(11 ; 52 \%)\end{array}$ & "battle," "warriors," "fighting in a battle" \\
\hline & Object $(21 ; 37 \%)$ & Orchestra $(1 ; 5 \%)$ & "playing in an orchestra" \\
\hline & & $\begin{array}{l}\text { Reflection } \\
(3 ; 60 \%)\end{array}$ & "reflection" \\
\hline & $\begin{array}{l}\text { State of mind } \\
(5 ; 9 \%)\end{array}$ & $\begin{array}{l}\text { Anticipation } \\
(2 ; 40 \%)\end{array}$ & "anticipation of facing something hard" \\
\hline & & $\begin{array}{l}\text { Positive emotion } \\
(3 ; 75 \%)\end{array}$ & $\begin{array}{l}\text { "satisfaction when something hard has } \\
\text { been achieved" }\end{array}$ \\
\hline & Emotion $(4 ; 7 \%)$ & $\begin{array}{l}\text { Negative emotion } \\
(1 ; 25 \%)\end{array}$ & "grief," "sadness" \\
\hline & & Space $(1 ; 25 \%)$ & "free space" \\
\hline Men $(57,100 \%)$ & Space $(4 ; 7 \%)$ & Castle $(3 ; 75 \%)$ & "reminds me of a castle" \\
\hline
\end{tabular}




\begin{tabular}{|c|c|c|c|}
\hline & & $\begin{array}{l}\text { Glory/victory } \\
(3 ; 15 \%)\end{array}$ & $\begin{array}{l}\text { "I fell but I've gotten up and won," } \\
\text { "victory" }\end{array}$ \\
\hline & & Majesty $(3 ; 15 \%)$ & "greatness of a man" \\
\hline & & Power $(7 ; 35 \%)$ & "power," "force" \\
\hline & & Danger $(5 ; 25 \%)$ & "terror" \\
\hline & Idea $(20 ; 34 \%)$ & Evil $(2 ; 10 \%)$ & "something evil" \\
\hline & & Nature $(3 ; 13 \%)$ & "some kind of a meadow" \\
\hline & & $\begin{array}{l}\text { Battle/battle } \\
\text { objects } \\
(20 ; 83 \%)\end{array}$ & $\begin{array}{l}\text { "battle atmosphere," "battle," "getting } \\
\text { ready for a battle," "a view after a battle" }\end{array}$ \\
\hline & Object $(24 ; 41 \%)$ & $\begin{array}{l}\text { Orchestra } \\
(1 ; 4 \%)\end{array}$ & "orchestral music" \\
\hline & & $\begin{array}{l}\text { Reflection } \\
(1 ; 33 \%)\end{array}$ & „thinking about final matters” \\
\hline & $\begin{array}{l}\text { State of mind } \\
(3 ; 5 \%)\end{array}$ & $\begin{array}{l}\text { Anticipation } \\
(2 ; 67 \%)\end{array}$ & $\begin{array}{l}\text { "something is about to happen, what will } \\
\text { happen next?" }\end{array}$ \\
\hline & & $\begin{array}{l}\text { Positive emotion } \\
(1 ; 10 \%)\end{array}$ & "idyll” \\
\hline & $\begin{array}{l}\text { Emotion } \\
(10 ; 17 \%)\end{array}$ & $\begin{array}{l}\text { Negative emotion } \\
(9 ; 90 \%)\end{array}$ & "stress," "tension," "anxiety" \\
\hline \multirow[t]{11}{*}{ Evil $(58,100 \%)$} & Space $(1 ; 2 \%)$ & Space $(1 ; 100 \%)$ & "great spaces" \\
\hline & & $\begin{array}{l}\text { Glory/victory } \\
(5 ; 38 \%)\end{array}$ & "victory" \\
\hline & & Majesty $(1 ; 8 \%)$ & "sublimity" \\
\hline & & Power $(3 ; 23 \%)$ & "power," "force" \\
\hline & & Journey $(2 ; 15 \%)$ & $\begin{array}{l}\text { "group of friends embarking on } \\
\text { a journey," "journeys" }\end{array}$ \\
\hline & & $\begin{array}{l}\text { Adventure } \\
(1 ; 8 \%)\end{array}$ & "adventure" \\
\hline & Idea $(13 ; 68 \%)$ & Beauty $(1 ; 8 \%)$ & "beauty of nature" \\
\hline & & Nature $(1 ; 25 \%)$ & "beauty of nature" \\
\hline & & $\begin{array}{l}\text { Battle/battle } \\
\text { objects }(2 ; 50 \%)\end{array}$ & "triumph after a battle" \\
\hline & Object $(4 ; 21 \%)$ & $\begin{array}{l}\text { Orchestra } \\
(1 ; 25 \%)\end{array}$ & $\begin{array}{l}\text { "great orchestra in a beautiful concert } \\
\text { hall" }\end{array}$ \\
\hline & $\begin{array}{l}\text { State of mind } \\
(1 ; 5 \%)\end{array}$ & Hope $(1 ; 100 \%)$ & "hope" \\
\hline $\begin{array}{l}\text { Fellowship of the } \\
\text { Ring }(19,100 \%)\end{array}$ & Emotion $(1 ; 5 \%)$ & $\begin{array}{l}\text { Positive emotion } \\
(1 ; 100 \%)\end{array}$ & "happiness" \\
\hline
\end{tabular}

Note. The numbers and percentages in parentheses show the frequency of indication of the association at the respective categorization level for each motif group. 